\title{
The Reconstruction of Sociology in Eastern Europe-Expectations and Dilemmas
}

\author{
Mirjana Ule \\ Faculty of Social Sciences, University of Ljubljana, Ljubljana, Slovenia \\ Email: mirjana.ule@fdv.uni-lj.si
}

Received 30 June 2014; revised 2 August 2014; accepted 16 August 2014

Copyright (C) 2014 by author and Scientific Research Publishing Inc.

This work is licensed under the Creative Commons Attribution International License (CC BY). http://creativecommons.org/licenses/by/4.0/

cC) (i) Open Access

\section{Abstract}

The article raises two questions: why do sociologists in Western Europe hold expectations of theoretical innovations in sociology in (post-)transitional Eastern European countries, and why is it that sociologists from Eastern Europe do not meet these expectations. The assumption is that these expectations are primarily a response to the theoretical crisis of modern sociology itself, rather than the effect of its knowledge of changes in transitional countries or its willingness to really listen to sociologists from those countries and accept them as equal partners. The attempt to answer the second question involves an analysis of the multilayered reality of sociology in postsocialism, including the loss of the socialist and civil-society utopias which have been replaced by pragmatic endeavors to re-establish a market society and its institutions. Despite the differences between the social situations in the East and West, today's "Eastern" and "Western" social scientists are confronted by similar global problems and challenges. While the present crisis of the capitalist economy and neo-liberalism certainly has its structural causes, what needs to be questioned here are the very assumptions underlying the world order and the key mechanisms of its functioning.

\section{Keywords}

Transition, Problem-Oriented Sociology, Utopia, Substantive Rationality

\section{Introduction}

It seems contradictory that in the period of the last two decades when Central and Eastern Europe (CEE) was undergoing massive and profound changes, with past images of the world collapsing, sociologists have hardly provided a response. Even the milestone events of the 1990s, i.e. the collapse of Yugoslavia and the Balkan wars, changes in Russia as the successor to the great Soviet Empire along with the difficult constitution of independent 
states arising from its former satellite countries, remained sociologically relatively un-thematised.

The East and the West alike just had to content themselves with some stereotypical generalizations about the crisis of socialism and the necessary transition to democracy and a market society. Not only did the construction of "big" theories fail to take place but also did theories of a medium range, such as explanations of the (re-)privatization processes, the introduction of democratic institutions, the relationship between the market and the state, changes in cultural consumption and the modernization of the economy.

The article deals with the questions of why sociologists in Western Europe hold expectations of theoretical innovations in sociology in (post-)transitional Eastern European countries, and why is it that sociologists from Eastern Europe do not meet these expectations. The assumption is that these expectations are primarily a response to the theoretical crisis of modern sociology itself, rather than the effect of its knowledge of changes in transitional countries or its willingness to really listen to sociologists from those countries and accept them as equal partners. The reasons for unrealized expectations about sociological innovations will be highlighted and the causes and forms of the deconstruction of sociology in transitional countries will be articulated. The heterogeneity of sociology in CEE countries will be pointed out. The article concludes with the finding about the need for substantive and not merely formal rationality of sociology in order to exceed the current crisis and respond to the traps of globalization and the neo-liberal ideology.

\section{The Crisis of Sociology and the Search for New Utopias}

The Western expectations of Eastern sociology and (post-)transitional countries ${ }^{1}$ are often based on the assumptions that sociological theory in former socialist countries, after having long been suppressed by Marxist ideology and politics, was underdeveloped and that after years of ideological constraint Central and Eastern European social scientists are now finally able to work and create freely (Buroway, 1999; Tamás, 1999; Kolko, 2006). Accordingly, many creative sociologists are expected to finally flourish in these circumstances and produce new theoretical concepts to make up for the shortcomings of their past.

Especially in the 1980s it seemed that the march of democracy in Central and Eastern Europe had started to bring new possibilities to (former) socialist countries. Many respected social scientists in these countries played a visible role in such processes (Keen \& Mucha, 2004). They were engaged in civil society movements, theoretically thematised what was going on, and articulated the need for a political change. Yet, is this a justified basis for expecting innovations in the social sciences and sociology to take place in this very part of the world? How are sociologists here suddenly to produce new theoretical innovations when the utopias which for so long substantiated their work have collapsed?

Therefore, two questions arise: why are there expectations (mainly in the West) of theoretical innovations in sociology in post-socialist countries, and why do the sociologists there not meet them? While we are only able to give a hypothetical answer to the first question-namely, that there are not enough analyses and discussions available on what kind of innovations are expected from the East, and what kind of innovations the West is even ready to accept—what is more interesting here is why these expectations have emerged in the first place. While sociologists did produce theories throughout the entire socialist period, at least for the territory of former Yugoslavia it could be claimed that they were only rarely listened to by the West, with the exception of some dissident voices. Another reason for this is the many "informational barriers" due to which these sociologists also remained rarely heard by their colleagues in other socialist countries. That is what makes us assume that these expectations primarily emerge as a reaction of sociologists to the deficiencies of modern sociology, and especially to the theoretical crisis of modern sociology, rather than a consequence of the weak knowledge of changes occurring in post-socialism.

\footnotetext{
${ }^{1}$ In modern "transitology", namely in studies of the process of change from authoritarian regimes to democracies, different terms are circulating which refer to states after the decline of socialism: post-socialism, post-communism, transition, post-transition (see Tokes, 2000). All of these terms are completely hollow, referring more to where we have come from than to where we are going. These terms are metaphors implying a historical lag behind the "developed" Western countries, for which the afflicted countries should quickly compensate, which means they automatically acquire the status of second-rate countries. Moreover, these terms are too wide as the expressions "transitional" and "post-transitional countries" are also often used for Spain, Portugal and Greece of the 1970s and various other countries of the Third World. However, given the lack of more adequate expressions, the terms "post-socialism" and "post-transition" will also be used here. The term "post-socialism" will be used to denote the period after the collapse of socialism and the formation of new economic and political structures. The term "post-transition" will be used to describe the decade after that, when the question of how to go on, for example how to transit from the previous mainly industrial modernisation to a post-industrial modernisation, and the term "(post-)transition" will be used to describe the whole process of transition from socialism and after that. In looking for an answer to this question, the Eastern European post-transitional countries are not alone but are sharing their search with other countries, such as those of Southern Europe.
} 
For some time, leading contemporary sociologists such as Anthony Giddens, Peter Berger, Immanuel Wallerstein and many others have been talking about a reflexive deficiency which is felt in "Western" sociology. In an interview for The Guardian carrying the alarming title "A Call to Arms", Anthony Giddens noted that academic sociology had vanished from the public space and that it was giving irrelevant answers to the questions of globalization and communication revolution (Giddens, 2006). Giddens suggests that the decline of sociology stems from the rise of market fundamentalism and the impotence many people feel in the face of the future. Further, Peter Berger sees sociology as being the victim of two mistakes, i.e. methodological fetishisms and ideologisations (Berger, 2002).

On the other hand, Immanuel Wallerstein is looking for an exit from the crisis of sociology in "utopistics", in the form of a "serious assessment of historical alternatives, the exercise of our judgment as to the substantive rationality of alternative possible historical systems" (1998: p. 2). In his introduction to an extensive collection of papers on the crisis of modern sociology, Stephen Cole (Cole, 2001) writes that social constructivism is perhaps not an adequate description of the natural sciences, yet it comes in very handy for sociology because from the cognitive point of view this means "that what sociologists believe to be true about human behavior has very little to do with evidence from empirical world; rather it is mostly a result of ideology, power, authority, and other social processes" (Cole, 2001: p. 8).

Therefore, the expectations of many sociologists that sociologists from post-socialist countries will make important theoretical innovations are perhaps more an expression of the unconscious repression of the worries about the state of modern sociology, and the transformation of these worries into hopes that the achievements of sociologists from the East might help do away with them. However, the question is whether the West has ever been open to an equal theoretical dialogue with the East. Discussions of Eastern Europe regularly invoke an image of the fall of the Berlin Wall as the final and complete victory of the "democratic" West over the "totalitarian" East and as the exemplary "End of History" (Fukuyama, 1992), leaving the impression of this being an event of mythical proportions marking the beginning of a completely new era in Eastern Europe, and one which needs to be continually returned to if the modern age is to be understood; as if all that is necessary is that the East reaches its democratic "maturity" and carries out the task of removing the ruins of the old (autocratic) system and builds a new, democratic one, while the West only needs to watch passively and wait complacently (Mason, 1992; Stokes, 1993; Ule, 2004)2.

The detail we all seem to overlook here is that the fall of the Berlin Wall held implications for both sides. Its debris littered not only Eastern Europe-Western Europe received its share as well. The responsibility for this task lies equally with social scientists on either side of the former Wall. If we fail to fulfil our professional responsibility, its ruins are likely to continue to sustain the line in our imagination dividing Europe into East and West. The theoretical anomy is not only a problem of the East, but also a problem of the West. In the process of industrial and post-industrial modernization, the West has not only been radically secularized, but has also lost its sense of myths and epic stories. It has also lost a sense of utopias.

\section{The De-Construction of Sociology in Transitional Societies}

The attempt to answer the second question - why sociologists in post-transitional countries have not met the expectations of a theoretical turn or the ascent of sociology in post-socialist countries-is more complex and involves several partial answers.

From the standpoint of "Western" sociology, the abolition of the one-party system and social ownership in the former socialist societies was viewed as an act of "creative destruction" (Keen \& Mucha, 2004). Yet, despite the elimination of much of the non-democratic ballast and the enabling of some important democratic and economic innovations in the face of economic globalization and the struggle for a new world order, many of the gains of democracy such as the welfare state, media autonomy, social movements, civil society and trade suddenly appeared not to be functioning. This process calls for an in-depth social analysis and critique which are no less urgent than the analysis and criticism of the East in its efforts to do away with its outdated autocratic political systems. However, such analysis and critique should become the task of both sociologists in (post-)transitional countries as well as Western sociologists. They may reveal the hidden prejudices and interests of Western social politicians, social scientists and "advisers" to (post-)transitional societies.

\footnotetext{
${ }^{2} \mathrm{~A}$ typical case of such understanding is the famous American PBS documentary movie "Heaven on Earth: The Rise and Fall of Socialism" (2005).
} 
The collapse of socialism and process of "recapitalizing" post-socialist societies was not simply a process of liberation from the mechanisms of authoritarian state-party rule but also a traumatic process of the loss of illusions and utopias. These not only involved ideologised images of a socialist society of equality and brotherhood, but also the image of democracy that was emerging in the last decade of socialism at a time of the mass activation of people within civil society movements, which were outside of the system and represented the driving force of changes within the system. That is where the idea and utopia of democracy were generated, and were based not on partitocracy but on people's co-governance of fundamental social processes (Killingsworth, 2012).

It is this image of democracy that encouraged people in the former socialist countries to commence the transition, and it is this very image which, soon after the consolidation of a parliamentary democracy, proved to be an illusion. In this phase of transition, shattered illusions and political utopias were replaced by pragmatic work on introducing market laws into the economy, the reprivatizing of state ownership, consumerism, and joining the European integration processes. This pragmatism did not only discourage or even block the development of civil society movements but also the need for sociological imagination, the creation of integral concepts and theoretical reflection and, moreover, caused the space available for public theoretical reflection in these societies to actually shrink rather than open up anew (Howard, 2003).

It seemed that sociologists in (post-)transitional countries found themselves in a similar position as their countries. With the period of their transition from socialism to democracy coming to a close, they still do not know how to position themselves in today's globalized world. Although some more successful post-socialist or post-transitional countries have managed to join European integrations (the EU), their main task may still be awaiting them: namely, how to develop social, economic and political structures which will be "competitive" with the most developed countries. The lack of such development would mean these countries are remaining "second-rate" countries which would largely have to bow down to the interests of "developed" European countries and the USA, and "copy" foreign solutions to various problems.

The key moment in understanding the changes in sociology in post-socialism was the reconstruction of sociology through the re-organization of the existing sociological institutions, theories, methods and research topics. This occurred in the context of and in response to the demands of the newly emerging market, the media, and the institutions associated with the transformation, as well as Western commercial interests in international organizations. One of the most significant institutional developments in CEE sociology was the proliferation of entirely new actors on the institutional scene, namely private commercial research institutes or centers mostly concerned with public opinion polls and/or market research.

According to Keen and Mucha, the suppression of a potential theoretical renaissance of sociology may originate in some sort of "colonisation" of CEE sociology that is within the global intellectual division of labor largely reducing CEE sociologists to the role of data suppliers for their Western counterparts (Keen \& Mucha, 2004: p. 135) ${ }^{3}$. Instead of promoting critical sociological thought, these conditions have been strengthening the private commercial research interests. A number of institutes or centers have emerged which are mostly concerned with public opinion polls and/or market research. Although new research topics have opened up, such as privatization, globalization, unemployment and underemployment, international integrations, social stratification and inequality, social mobility and social marginalization (together with some important topics from the pre-transitional era), as well as the exploration of a range of social problems of the so-called new "risk society" (many of which emerge from transition processes and include poverty, homelessness, crime, delinquency, prostitution, health and illness, and the black market), current sociological research in CEE sociology remains the province of a small, relatively marginalized community of specialists within the discipline.

What the Finnish sociologist Iris Virtasalo stated on the status and development of social science research in CEE countries is also very much true of sociology itself: "As a consequence of the communist rule, social sciences were not seen as essential in the emerging new economies as many other disciplines were, and not enough resources were channeled into them. The benefits offered by social science research to society were not fully understood in CEE countries. Social scientists have not been seen as providers of adequate responses to complex societal issues and to facilitating social transformations" (Virtasalo, 2006: p. 10).

In these new conditions, a theoretically profound type of sociological thought no longer seems adequate, as if the above-average moral and political courage needed to achieve at least basic scientific integrity and objectivity

\footnotetext{
${ }^{3}$ Here Keen and Mucha quoted the Nemedi and Robert article "More Evolution than Revolution: Sociology in Hungary 1990-2000": "Sociology, which was once conceived as the critical consciousness and conscience of 'its' society, is becoming an international research machine” (see Keen \& Mucha, 2004).
} 
are no longer required. Unfortunately, such an attitude contributes largely to the erasure and/or revision of the historical courage, making it difficult today to achieve the necessary critical distance vis-à-vis the existing conditions. If in the past independent theoretical output, at least in a rudimentary form, did not exist or was interrupted, then today it has to be re-introduced or revived. However, this requires time and it is unrealistic to expect any significant achievements outside of mainstream sociological work. Namely, inherently relevant sociology leads to important critical insights into modern social life which may help in transcending the historical obstacles.

Sociology in CEE has been predominantly problem-oriented, while Western sociology is basically paradigmoriented (Lengyel, 2004). While the possibilities of recognizing relevant social problems seem more direct in problem-oriented sociology that keeps the sociological imagination awake and establishes more direct contact between personal and historical experiences, its conceptual frameworks are more incidental. On the other hand, while paradigm-oriented sociology allows for a deeper and more systematic analysis of phenomena, resulting in the greater cumulative dynamism of scientific knowledge, its relevance to social practice is more indirect.

Problem-oriented sociology is not only characterized by its closeness to politics but also by its socially critical attitude: through direct reflections focusing on the presentation of topical social problems, pressing deficiencies and injustices, without differentiating between social and scientific agendas. These strong representations of problem-oriented sociology within CEE sociology allow the latter greater flexibility and responsiveness to immediate problems of the social environment.

In spite of this, there exists a grave information asymmetry that is unfavorable to CEE sociology. CEE sociologists are under-represented in international periodicals, book publications and research references considering the volume of sociological work that is produced. In addition to the language barrier, this information asymmetry strongly relates to the predominance of the paradigm-oriented approach in the West, the results of which attract more interest from professional journals (Lengyel, 2004: p. 151). This also applies to many sociological communities in the Southern European countries, and to small nations in general. However, the credit for the rejection of lifeless dogmas and apologies chiefly goes to the tradition of critical sociology.

\section{The Non-Uniformity of CEE Sociology}

Moreover, the picture of the former socialist world is also not as uniform as may seem at first glance. At least for Slovenia and former Yugoslavia, it can be safely argued that both boasted advanced sociological and socially critical scientific theory in which the ideological stereotypes of the "dictated Marxism" were discarded for practical reasons no later than at the end of the 1970s. Actually, several notable groups had cultivated a critical theory of society since the 1960s, including a group of social scientists affiliated with the "Praxis" journal.

Many other researchers and theoreticians in former Yugoslavia regularly kept abreast of current world developments in the social sciences. Yugoslavia hosted widely acclaimed international gatherings of social scientists, for example, the Korčula School, the regular sociological symposia in Dubrovnik etc. Finally, we should not forget that some Western scientists and not only those with a leftist bent viewed the official Yugoslav socio-political doctrine, known as the theory of self-management, favorably. If nothing else, it was regarded as an interesting experiment, a promising "third way" between the two poles of communism and capitalism.

Another feature of sociology in former socialist countries was that it wavered between sentimental enthusiasm and anomic resignation. In many former socialist countries, opposition movements had developed years before the collapse of the socialist regime, albeit these efforts were mainly invisible, hidden from the public eye, and denied access to the mass media. Autonomous sociological thought was an inevitable component of the opposition.

In the new circumstances, the extraordinary ethical or political courage needed to achieve at least basic scientific honesty and objectivity no longer seemed required. However, what currently seems to be even more difficult to achieve is a critical distance vis-à-vis actual post-transitional societies. The explanation of the absence of new scientific thought and theory is very prosaic. The development of social reflection, and consequently of sociology, strongly depends on the success of the educated middle class. Yet it is precisely members of this middle class who are forced, under the pressure of neo-liberal economic policies and the employment crisis, to make the difficult decision on whether to invest their time and effort in cultural or economic capital; needless to say, if they wish to improve and even maintain their present economic situation they have no choice but to opt for more profitable commercial activities which involve less intellectual investment and less critical reflection. 
With a gap existing between the interests of the owners of economic capital and the owners of cultural capital, the development of an autonomous and critical intelligentsia is being hindered. While many university graduates, especially in the social sciences, cannot find jobs or have low wages, the owners of economic capital only seek economic success and profits and are not interested in cultural and scientific development.

Interestingly, in many respects the effects are similar to those marking our past when such an obstruction was caused by the monopoly of the single-party rule. Yet the economic and social conditions provided by the state in support of science during the socialist era enabled the development of sociological thought and theory at universities and institutes, although neither was put to public use. Today, sociological thought and theory are having a hard time securing public "approval” of the need for social research and studies. Post-socialist states show little interest in these, and are instead emphasizing pragmatic analyses such as public opinion surveys, market research and so on. The absence of reflection and critical theory in the public sphere may prove fatal to the development of young democracies. They could easily fall prey to a mixture of populist, nationalist or Europhobic policies.

Due to the numerous integration processes, including enlargement of the European Union as part of the complementary processes of globalization, the differences between (post-)transitional and Western European countries have been fading. While globalization has been blurring the differences between the two former blocs in Europe (we all find ourselves in the "same boat" heading towards globalization), new differences have been delineated between those countries which turn to nationalism and isolation from the outside world and those countries which pursue open policies in an attempt to become integrated into Europe as soon as possible. These new differences may be equally painful and dangerous.

\section{Conclusions: In the Search for Substantive Rationality in Sociology}

It can thus be concluded that today's Eastern and Western social scientists are confronted by similar global problems and challenges. The crisis of the capitalist economy and neo-liberalism certainly has its structural causes; however, what we as social scientists should be concerned about is that in many respects we have ceased to question the very assumptions on which the world order is based as well as the key mechanisms of its functioning. Globalization is actually emerging as some kind of new political and economic hegemonic power. Opaque and hard to perceive, it renders the individual less able to defy it through some Marcusean "Great Refusal".

In both the East and West the individualization of risks, which is one of the consequences of globalization and late modernity, brings about situations that once called for collective or political action, whereas now they are interpreted as unfortunate life stories of this or that person which only that particular person can solve through individual action. The individualization of risks goes hand in hand with the individualization of responsibilities and achievements (Beck \& Beck-Gernsheim, 2002). The combination of the pressure to accept individual responsibility (which is a mechanism of disciplining) and the realistic experience of helplessness produce strong feelings that risks and dangers are omnipresent, whereby in the absence of collective support structures and strategies one can only rely on oneself in managing these risks. Uncertainty and doubt have pervaded all aspects of life.

Facing the risks of individualization requires a different type of rationality than formal or economic rationality. It requires value-oriented choices, conceptions of alternative life courses, and the construction of alternative definitions of social situations. Limiting discussions on risk merely to profit and benefit calculations according to patterns of formal or scientific rationality means narrowing the space of the social sciences which need to consider wider social contexts, historical experiences, and the construction of alternative scenarios of social development. Unlike Francis Fukuyama, who predicted the end of history almost a decade ago, Immanuel Wallerstein in his Utopistics invites us, or rather pleads to all of us who deal with social theory, to return to active contemplation about possible forms of the new world. Wallerstein defined utopistics as alternatives that may help in the development of substantive rationality in sociology (in accordance with Weber) to become more convincing and consequently more effective than the formal rationality (Wallerstein, 1998).

At the risk of appearing somewhat sentimental, the author would like to point out that the social sciences are inclined to seek solutions to predicaments caused by the domination of formal rationality (e.g. efficiency and cost-benefit analyses, rational decisions, value neutrality). The social sciences can show us the way to substantial rationality that takes the social and historical context of social activity and its goals into account and seeks alternatives to the existing social systems (Wallerstein, 2001). The feeling that sociology is in crisis is largely 
the result of this domination of formal rationality occurring inside and outside the professional field. The author also believes that sociology was too gullible to become engaged in competition with areas such as management, organization, system analysis, information and knowledge transfers, where all of these areas are in the domain of lawyers, information technology experts, organizers and other only seemingly "sociology-related experts". The author assumes that this is one of the main reasons that sociology was so unprepared for the conceptual confrontation with the causes and consequences of the global economic and social crisis emerging in 2008. It seems that in Europe sociology only rarely finds the necessary self-confidence to say out loud that formal rationality is just a temporary and apparent solution to the uncertainties and risks produced by contemporary societies, and that the sociologists should be more decisive in resisting this alluring and easy conformity, for example by more decisively criticizing neo-liberal theories that argue for greater economic efficiency through the reduction of "social costs" and by more actively supporting the emerging global civil society (Bartelson, 2006). In fact, once again we are approaching a time of many milestone events and their accompanying risks, hopes and fears-a time of comprehensive European integration which began with the EU's enlargement and which highlights the lines of new global conflicts between the emerging European supra-state and other centers of power across the world, particularly the USA and China. The author wonders if Europeans are ready to confront such challenges and will be able to look beyond certain false alternatives such as the unacceptable reduction of the complexity of social issues as is promoted by right and left totalitarianisms, etatisms and so on.

Hopefully, after the initial euphoria over the collapse of socialism and the first experiences with "real capitalism" in post-socialist countries, a second generation of theorizing is appearing which "probes more deeply into the fabric of society" (Buroway, 1999: p. 302) ${ }^{4}$. The very idea of the social is in abeyance, threatening the existence of the social sciences, including sociology, but not the economic sciences or political sciences that have become ever more asocial or antisocial. Indeed, we can go further and declare that sociology itself is swiftly becoming a real utopia, providing a concrete imagination for an alternative world incompatible with capitalism (Buroway, 2009). "The collapse of communism may not spell the end of socialism, but it has certainly intensified third-wave marketization around the globe. As third-wave marketization erodes civil society, it threatens all institutions outside market and state, the foundations of real utopias... As such we need a reflexive ethnography to propagate the sociological imagination, the prophetic glue that can bind real utopias together while holding at bay the destructive forces of market and state. Sociology, if it is to survive, may have no alternative but to go public" (Buroway, 2009: pp. 277-278).

After the period of the mass exporting of neo-liberal economic theories from the "West" to the "East" at the start of the transition, even the strongest proponents of capitalist shock therapy saw that markets can be created overnight but their character and consequences cannot be controlled. We cannot hope for them to produce more freedom and a higher kind of social reflection. The author also suspects that even some improved economic policies, which propose a less shocking transition from socialism to capitalism, are not enough. They support the emerging managerial capitalism led by the "coalition" of some former party technocrats and members of the new cultural bourgeoisie, while what is needed is a developed level of social accountability and civic consciousness in order to evade primitive forms of accumulation or even disaccumulation.

\section{References}

Bartelson, J. (2006). Making Sense of Global Civil Society. European Journal of International Relations, 3, 371-395.

\footnotetext{
${ }^{4}$ The author agrees with Buroway that there is a strong analogy between post-socialist and post-colonial studies. Like post-colonial theories attempting to grapple with the continued subordination of colonised people and with their disillusions with national independence, post-socialist thinking could also reach similar conclusions, namely that the free market, liberal democracies and national independence are all chimeras binding new nations under the Western hegemony (Buroway, 2001: p. 1118). Buroway even dreams of the possibility of a post-socialist revisionist history "that, while not denying communist horrors, will recognize socialism potentialities" (Buroway, 2001: p. 1118). He believes that "socialism did not have a chance-for world historic reasons rather than internal limits"-like capitalism "to refashion itself before it was overrun" (ibid.). Here the author only partly agrees with Buroway as she claims that it seems quite clear that socialism, at least as the economic and political system of one-party-regimes, mainly fell into decline because of its internal limits. However, at the same time it is also true that in its history socialism produced and distorted many concrete solutions of social problems and democratic initiatives which may be worth preserving or reviving. This is especially important since 2008 when the neo-liberal concepts of capitalism are experiencing a massive empirical falsification, and at least the more developed post-transitional states may be moving away from the model of managerial capitalism towards a form of socially responsible market society.

${ }^{5}$ Here the author is referring to the analysis of post-socialist societies given by Gil Eyal, Ivan Szelény and Eleanor Townsley (Eyal et al., 2001). They interpreted social conditions in some more developed post-socialist societies (like Hungary, Czech Republic, Poland) as "capitalisms without capitalists" in contrast to the Western "capitalism with capitalists", and to the conditions in Russia and some less developed post-socialist countries as "capitalists without capitalism".
} 
http://dx.doi.org/10.1177/1354066106067348

Beck, U., \& Beck-Gernsheim, E. (2002). Individualization. Institutionalized Individualism and Its Social and Political Consequences. London: Sage.

Berger, P. (2002). Whatever Happened to Sociology? First Things, 126, 27-29.

Buroway, M. (1999). Afterword. In K. Verdery, \& M. Burawoy (Eds.), Uncertain Transition: Ethnographies of Change in the Postsocialist World (pp. 301-312). Lanham: Rowman \& Littlefield.

Buroway, M. (2001). Neoclassical Sociology: From the End of Communism to the End of Classes. The American Journal of Sociology, 106, 1099-1120. http://dx.doi.org/10.1086/320299

Buroway, M. (2009). The Extended Case Method. Four Countries, Four Decades, Four Great Transformations and One Theoretical Tradition. Berkeley: University of California Press.

Cole, S. (2001). Introduction: The Social Construction of Sociology. In S. Cole (Ed.), What's Wrong with Sociology (pp. 7-36). New Brunswick: Transaction Publ.

Eyal, G., Szelény, I., \& Townsley, E. (2001). Making Capitalism without Capitalist. The New Ruling Elites in Eastern Europe. New York: Verso.

Fukuyama, F. (1992). The End of History and the Last Man. New York: The Free Press.

Giddens, A. (2006). A Call to Arms. The Guardian, 26 November 2006.

Howard, M. M. (2003). The Weakness of Civil Society in Post-Communist Europe. Cambridge: Cambridge University Press. http://dx.doi.org/10.1017/CBO9780511840012

Keen, M., \& Mucha, J. (2004). Sociology in Central and Eastern Europe in the 1990s: A Decade of Reconstruction. European Societies, 6, 123-147. http://dx.doi.org/10.1080/14616690410001690736

Killingsworth, M. (2012). Civil Society in Communist Eastern Europe. Colchester: ECPR.

Kolko, G. (2006). After Socialism: Reconstructing Critical Social Thought. London: Routledge.

Lengyel, G. (2004). On the Origin and Variety of Problems in Current Central and East-European Sociology (a Reflection on the Article of Keen and Mucha). European Societies, 6, 149-157. http://dx.doi.org/10.1080/14616690410001690691

Mason, D. S. (1992). Revolution in East-Central Europe: The Rise and Fall of Communism and the Cold War. Boulder, CO: Westview Press.

Stokes, G. (1993). The Walls Came Tumbling Down: The Collapse of Communism in Eastern Europe. New York: Oxford University Press.

Tamás, P. (1999). Woyeuroder Mitgestalter? Die Sozialwissenschaften Ostmitteleuropas in der Systemtransformation. In L. Faltan, M. Kusy, \& E. Farkasová (Eds.), Europe: Expectation and Reality. The Challenge for the Social Sciences. Bratislava: Slovak Academy of Sciences, UNESCO.

Tokes, R. L. (2000). “Transitology”: Global Dreams and Post-Communist Realities. Central Europe Review, 2, 10. http://www.ce-review.org/00/10/tokes10.html

Ule, M. (2004). No Time for Complacency: Sociology after Socialism. European Societies, 6, 159-166. http://dx.doi.org/10.1080/14616690410001690682

Virtasalo, I. (2006). Status and Developments of Social Science Research in Central and Eastern Europe. Helsinki: ESF, University of Helsinki.

Wallerstein, I. (1998). Utopistics: On Historical Choices of the Twenty-First Century. New York: Free Press.

Wallerstein, I. (2001). Unthinking Social Sciences. The Limits of the Ninety-Century Paradigms. Philadelphia, PA: Temple University Press. 
Scientific Research Publishing (SCIRP) is one of the largest Open Access journal publishers. It is currently publishing more than 200 open access, online, peer-reviewed journals covering a wide range of academic disciplines. SCIRP serves the worldwide academic communities and contributes to the progress and application of science with its publication.

Other selected journals from SCIRP are listed as below. Submit your manuscript to us via either submit@scirp.org or Online Submission Portal.
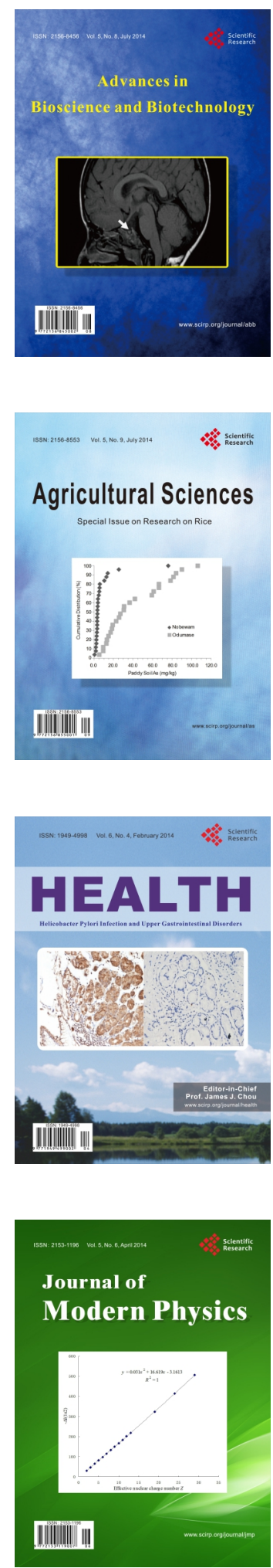
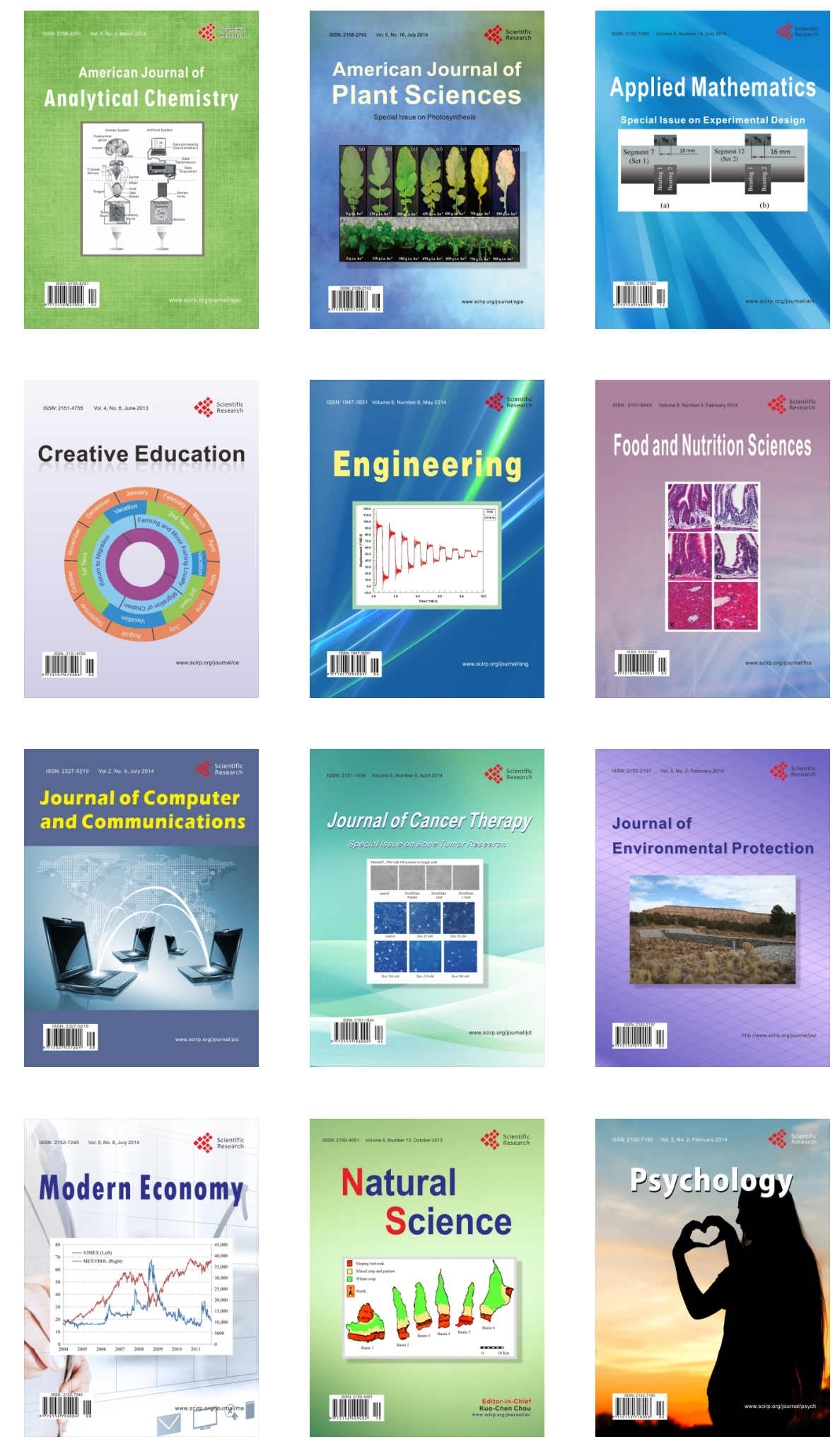